\title{
Asparagine: A Metabolite to Be Targeted in Cancers
}

\author{
Jie Jiang ${ }^{1}$, Sandeep Batra ${ }^{2, *}$ and Ji Zhang ${ }^{1,3, *}$ \\ 1 Herman B Wells Center for Pediatric Research, School of Medicine, Indiana University, \\ Indianapolis, IN 46202, USA; jj15@iu.edu \\ 2 Riley Hospital for Children at Indiana University Health; Indianapolis, IN 46202, USA \\ 3 Department of Biochemistry and Molecular Biology, School of Medicine, Indiana University; \\ Indianapolis, IN 46202, USA \\ * Correspondence: batras@iu.edu (S.B.); jzh1@iu.edu (J.Z.)
}

Citation: Jiang, J.; Batra, S.; Zhang, J. Asparagine: A Metabolite to Be Targeted in Cancers. Metabolites 2021, 11, 402. https://doi.org/10.3390/ metabo11060402

Academic Editors: Jiyeon Kim and Claire Pecqueur

Received: 13 May 2021

Accepted: 15 June 2021

Published: 19 June 2021

Publisher's Note: MDPI stays neutral with regard to jurisdictional claims in published maps and institutional affiliations.

Copyright: (c) 2021 by the authors. Licensee MDPI, Basel, Switzerland. This article is an open access article distributed under the terms and conditions of the Creative Commons Attribution (CC BY) license (https:// creativecommons.org/licenses/by/ $4.0 /)$.

\begin{abstract}
Amino acids play central roles in cancer progression beyond their function as building blocks for protein synthesis. Thus, targeting amino acid acquisition and utilization has been proved to be therapeutically beneficial in various pre-clinical models. In this regard, depletion of circulating asparagine, a nonessential amino acid, by L-asparaginase has been used in treating pediatric acute lymphoblastic leukemia (ALL) for decades. Of interest, unlike most solid tumor cells, ALL cells lack the ability to synthesize their own asparagine de novo effectively. However, only until recently, growing evidence suggests that solid tumor cells strive to acquire adequate amounts of asparagine to support tumor progression. This process is subjected to the regulation at various levels, including oncogenic signal, tumor-niche interaction, intratumor heterogeneity and dietary accessibility. We will review the literature on L-asparaginase-based therapy as well as recent understanding of asparagine metabolism in solid tumor progression, with the hope of shedding light into a broader cancer therapeutic strategy by perturbing its acquisition and utilization.
\end{abstract}

Keywords: asparagine; L-asparaginase; acute lymphoblastic leukemia; asparagine synthetase; stress response; metabolic adaptation; mTORC1; GCN2; ATF4

\section{Introduction}

Amino acids are the fundamental building blocks for the synthesis of protein, which contributes to the majority of biomass in proliferating mammalian cells [1]. Growing evidence suggests that the demands for amino acids in proliferating mammalian cells, such as cancer cells, go beyond their requirement for global protein synthesis [2]. As a result, restricting amino acid acquisition and utilization has been proposed to be a potential therapeutic strategy to limit cancer cell growth while leaving the normal tissues largely intact. A compelling example of such therapy is the application of L-asparaginase to deplete circulating asparagine in treating pediatric ALL patients for decades [3]. Despite the successful application in ALL patients, L-asparaginase has not been proved to be effective in most other cancer types, suggesting their reduced dependency on circulating asparagine. However, recent advancements in cancer cell metabolism suggest that asparagine plays critical roles in solid tumor progression, and is therapeutically explorable. In this review, we will summarize the application of L-asparaginase in ALL, discuss the potential mechanisms driving therapeutic resistance, and highlight the most recent studies elucidating the role of asparagine as a nutrient or signaling modulator to support solid tumor progression, and discuss therapeutic implications.

\section{Asparagine and L-Asparaginase in Acute Lymphoblastic Leukemia (ALL) \\ 2.1. History of L-Asparaginase}

L-asparaginase was first discovered in 1953 by two studies that identified anti-tumor activity of guinea pig serum toward transplanted lymphomas [4,5]. Later on, several 
studies confirmed that the L-asparaginase activity found in the guinea pig serum is responsible for this anti-tumor effect [6-9]. Native L-asparaginase purified from E. coli was first used to induce remission in ALL in the 1960s [10], and ever since has been used extensively in patients with ALL and acute lymphoblastic lymphoma (ALLy) [3,11]. It exerts its metabolic effect by catabolizing asparagine to aspartate and free ammonium in the circulation [3]. In 1980s, chemically modified E. coli L-asparaginase was developed using a polyethylene glycol moiety conjugation, also known as pegylated L-asparaginase (PEG-L-asparaginase) [12]. This chemical modification significantly prolongs its half-life and reduces antigenicity, but with similar pharmacokinetics (PK) $[13,14]$. Asparaginase can also be derived from Erwinia chrysanthemi. In patients with severe allergic reactions to native E. coli L-asparaginase or PEG-L-asparaginase, Erwinia asparaginase is often substituted [15-17], as antibodies to native or PEG-L-asparaginase, usually do not cross react with the Erwinia-derived asparaginase. However, Erwinia asparaginase has a short half-life and has to be administered every $48-72 \mathrm{~h}$ [14]. While early studies demonstrated inferior outcomes with its usage, the dose frequency might have been suboptimal and lead to these results [18]. Indeed, recent studies have demonstrated adequate depletion with frequent administration of Erwinia asparaginase [16,19]. More recently, a new modified form, EZN-2285 (SC-PEG E. coli L-asparaginase or Cal-asparaginase) is under investigation, and will likely replace PEG-L-asparaginase use. EZN-2285 is produced by replacing the succinimidyl succinate (SS) linker in PEG-L-asparaginase with a succinimidyl carbamate (SC) linker, thereby leading to a more hydrolytic stability, and decreased susceptibility to hydrolytic removal of the PEG from the protein conjugate [20].

L-asparaginase is included in almost all current regimen for pediatric ALL/ALLy and ALLy due to its unique efficacy toward ALL/ALLy blasts. However, little is known on why other cancers are resistant to it $[10,21]$. One explanation is that compared to other cancer cells, ALL blasts express low levels of asparagine synthetase (ASNS) due to DNA hypermethylation on the gene promoter, and therefore rely on exogenous asparagine completely [22,23]. Metabolomic studies with genome-wide DNA methylation landscaping identified a small group of gastric and hepatic cancer cells that have similar features to ALL cells, raising the possibility to treat these cancers with L-asparaginase. Another interesting question is to develop humanized L-asparaginase to minimize antigenicity. Although evidence exists to support the possibility [24], mammals do not express functional L-asparaginase endogenously. In this regard, why only guinea pig serum contains Lasparaginase activity is still a mystery, since earlier studies using rabbit or horse serum did not identify anti-tumor activities [4]. Furthermore, when a functional L-asparaginase derived from lower organism is engineered into mammalian cells, it prevents mammalian cells from adapting to glutamine starvation [25]. These results suggest that loss of Lasparaginase activity during evolution may reflect a selective strategy to adapt to nutrient availability in the context of development.

\subsection{Clinical Responses to L-Asparaginase Treatment in ALL Patient}

Since its first application in patient, many clinical studies have been performed to optimize the usage of L-asparaginase in treating ALL. The Children's Cancer group (CCG) conducted a pivotal randomized clinical trial (CCG-1962) that established the effectiveness of PEG-L-asparaginase by comparing native to PEG-L-asparaginase in a randomized fashion [26]. PEG-L-asparaginase was given intramuscularly at $2500 \mathrm{IU} / \mathrm{m}^{2}$, single dose during induction and once during each delayed intensification phase. E. coli L-asparaginase (native form) was administered intramuscularly at a standard dose of $6000 \mathrm{IU} / \mathrm{m}^{2}$, three times weekly for 9 doses during induction and for 6 doses during each delayed intensification phase [26]. It was observed that patients who received PEG-L-asparaginase cleared their blasts more rapidly, had lower levels of detectable antibodies, and asparaginase levels persisted for a longer duration, compared to patients in the native arm of the study [26].

Frontline multi-institutional CCG studies (1941, 1962 and 1961) further established the ideal PK parameters for PEG-L-asparaginase, including adequate asparagine deple- 
tion $\leq 3 \mu \mathrm{M}$ achieved with serum asparaginase levels $\geq 0.1 \mathrm{IU} / \mathrm{mL}$. These studies also helped establish PK-based optimal dosing for Erwinia asparaginase $\left(25,000 \mathrm{IU} / \mathrm{m}^{2}\right.$, every 2-3 days) [27]. Dana-Faber Cancer Center reported that intravenous administration of PEG-L-asparaginase was safe and was similar to intramuscularly in children, with persistent and therapeutic serum asparaginase concentrations and minimal side-effects [28]. These results were confirmed in adult trials with pharmacodynamics (PD) demonstrating therapeutic enzymatic activity of $0.1 \mathrm{IU} / \mathrm{mL}$ or more for at least 3 weeks [29]. Of interest, Lasparaginase from Pseudomonas $7 A$ contains glutaminase activity with a higher $\mathrm{Km}$ toward glutamine as a substrate [30]. Although glutaminase activity was initially reported to be involved in effective asparagine depletion in ALL patients [31], other studies suggest that the glutaminase activity may not be central for its therapeutic effect at least in pre-clinical models in vivo [32-34].

Dose intensification of asparaginase therapy was investigated in a number of trials, however these resulted in increased side effects such as thrombosis, pancreatitis, severe hypoalbuminemia, and cachexia [35-37]. Recent reports also have suggested that highly intensified asparaginase treatment worsens the toxicity of other agents [38,39]. However, high risk B-precursor ALL patients receiving augmented Berlin-Frankfurt-Munster (BFM) therapy that includes 2-10 additional doses of PEG-L-asparaginase during post-Induction Intensification phases demonstrate improved outcomes [40]. Furthermore, patients with T-ALL who received intensified asparaginase also had improved outcomes on Pediatric Oncology Group (POG) trials [41,42]. The UKALL 2003 trial intensified PEG-L-asparaginase dosing (using a modified COG/BFM regimen) in standard and intermediate risk ALL patients, who were minimal residual disease (MRD) positive [36,37].

In summary, the clinical effect of L-asparaginase is determined by the formulations as well as the dose, route of administration and frequency of the treatment. In general, intensified regimen improves overall outcome but also introduces toxicities and side effects. Allergic reaction is one major side effect, which needs to be monitored closely but can be overcome with using substitutional approaches.

\subsection{Mechanism of Resistance to L-Asparaginase Treatment in ALL}

Similar to many other chemo-agents, another factor to limit the clinical efficacy of L-asparaginase is the potential development of resistance. As mentioned earlier, the development of allergic reactions post-treatment is one mechanism seen commonly with its use. These IgG-mediated allergic reactions are unpredictable, idiosyncratic and can vary greatly in severity, and clinical symptoms, and can range from a minor rash or urticaria or fever to severe anaphylactic reactions to none $[43,44]$. Even without a symptom, the high titers of IgG production can lead to a rapid clearance of L-asparaginase, known as silent inactivation. Indeed, both missed dosing and silent inactivation has been linked to a greater risk of ALL relapse [18,45]. In addition, macrophage-mediated phagocytotic process can also contribute to the clearance of L-asparaginase in vivo at least in a mouse model [46].

The molecular and cellular mechanisms that cause resistance to L-asparaginase treatment have been extensively studied in cell culture experiments. A key player in driving the resistance is the expression of asparagine synthetase (ASNS) [3,47], the rate limiting enzyme for de novo biosynthesis of asparagine (Figure 1A). Earlier studies using cell culture showed that the expression levels of ASNS in human leukemic cell lines correlate reversely with their sensitivity to L-asparaginase treatment in vitro and forced expression of ASNS is sufficient to confer resistance in sensitive leukemic lines [48]. Additional studies suggested that the lack of expression of ASNS in sensitive leukemic cells is due to the DNA hypermethylation in the promoter region of ASNS gene [22,23,49]. Furthermore, recent work from our lab and others have shown that the capacity of ALL cells to induce the expression of ASNS following L-asparaginase treatment is a key determinant conferring therapeutic resistance $[50,51]$. This induction requires two components: (a) the general control nonderepressible 2 (GCN2) to activate ATF4, an indispensable transcriptional factor for ASNS transcription [52], and (b) the promoter demethylation of ASNS gene, which allows 
ATF4 recruitment and transactivation [51] (Figure 1B). Of interest, recent work suggests that Zinc Finger and BTB domain-containing protein 1 (ZBTB1) is required for ATF4-dependent transcription of ASNS gene specifically in T-ALL cells through promoter occupancy [53]. In addition to the expression of ASNS itself, studies suggest that the availability of aspartate and glutamine, two indispensable substrates of ASNS, are also important for cellular adaptation to the depletion of exogenous asparagine [54,55]. However, in cell culture conditions, glutamine uptake is not a limiting factor and most cancer cells can use glutamine to synthesize aspartate de novo [56]. Therefore, it warrants further investigation whether there is a cell type specific mechanism, such as aspartate and/or glutamine availability contributes to the sensitivity to L-asparaginase treatment in cells that express high levels of ASNS $[54,55]$.

(A)

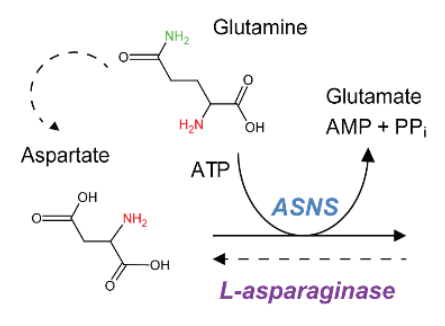

(B)

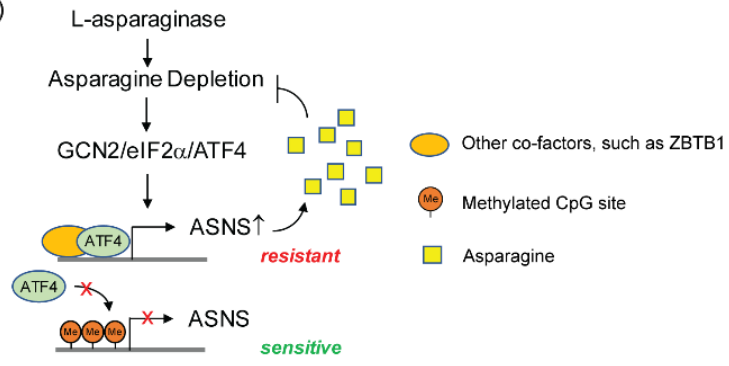

Figure 1. Asparagine de novo biosynthesis in driving L-asparaginase resistance. (A) ASNS catalyzes asparagine biosynthesis by using glutamine, aspartate and ATP. In proliferating mammalian cells, most aspartate is synthesized de novo by using oxaloacetate and glutamate as substrates. Since glutamate is produced through glutamine deamination, which can be further deaminated to fuel the TCA cycle to generate oxaloacetate, glutamine is the major carbon and nitrogen donor for aspartate biosynthesis [56]. Catabolism of asparagine to aspartate by L-asparaginase has not been reported in mammalian cells. (B) Asparagine depletion by L-asparaginase activates GCN2 pathway, leading to ATF4 accumulation, which turns on ASNS. As a result, cells synthesize more asparagine to mitigate the stress. However, ATF4 cannot be recruited to the ASNS promoter unless it is demethylated.

In contrast to the in vitro studies done in cell culture, contradictory conclusions were reached from clinical studies. Stams, et.al., showed that in ALL patients with TEL/AML1 fusion, despite that fact that a consistent increase in ASNS mRNA following L-asparaginase treatment was observed, no correlation was found in overall therapeutic responses [57]. However, this study was done in ALL patients with TEL/AML1 fusion, which is associated with good prognosis and high sensitivity to L-asparaginase in general. In addition, Su, et.al. reported that the level of ASNS protein is a better predictor of resistance to L-asparaginase treatment than mRNA [58]. However, a recent study with a larger cohort of T-ALL patient suggests that TLX1 positive T-ALL patients express low levels of ASNS mRNA and are more sensitive to L-asparaginase treatment [59]. Furthermore, the low expression of ASNS mRNA correlates with DNA hypermethylation in the promoter region of ASNS gene [59]. This study highlights the possibility to use ASNS mRNA expression and/or promoter methylation status of ASNS gene as a predictor for therapeutic responses. Thus, a larger cohort study including ALL patients that are more refractory to L-asparaginase treatment is needed. These studies also suggest that the genetic background of patients needs to be considered when interpreting the clinical results on therapeutic response/resistance.

In addition to the intrinsic effect of ASNS expression in ALL cells, microenvironment can also contribute to L-asparaginase resistance. Iwamoto et.al, reported that bone marrowderived mesenchymal cells (MSCs) express high levels of ASNS and thus can secrete asparagine to confer L-asparaginase resistance when ALL cells were co-cultured with MSCs [60]. Furthermore, bone marrow adipocytes can also protect ALL cells from Lasparaginase-induced cytotoxicity even though the mechanism is dependent on glutamine secretion [61]. In this study, obese children diagnosed with high-risk ALL has been found to have an increased risk of relapse than their lean counterparts [61]. Whether it reflects a mitigation of the glutaminase activity within L-asparaginase or represents an adaptive 
mechanism for ALL cells to use glutamine to drive de novo biosynthesis of asparagine warrants further investigation.

Although most studies on the molecular mechanisms of L-asparaginase resistance have been focused on the expression of ASNS, other mechanisms can be involved. Using a genome-wide synthetic lethal CRISPR/Cas9 screen, activation of WNT pathway was identified to synergize with L-asparaginase treatment in inducing cell death in ALL cells that are resistant L-asparaginase treatment alone [62]. Mechanistically, WNT pathway suppresses GSK3-dependent proteolysis, which catabolizes unwanted cellular proteins as a scavenging pathway to maintain intracellular asparagine levels (Figure 2). However, in this study, whether the WNT/GSK pathway interferes with the expression of ASNS was not investigated. Similarly, autophagy is another mechanism for amino acid scavenging $[1,63]$. Along this line, activation of autophagy by L-asparaginase treatment has been found to protect ALL cells from death, even though it is still unclear whether intracellular asparagine levels can be restored through this mechanism or not [64] (Figure 2). Another study using genome-wide RNAi screen identified huntingtin associated protein 1 (HAP1) as a biomarker and a driver for the sensitivity to L-asparaginase treatment [65]. As a result, loss of HAP1 confers resistance to L-asparaginase treatment through preventing the release of calcium from endoplasmic reticulum (ER) and the subsequent calcium-dependent cell death [65] (Figure 2). Indeed, pharmacogenetic and functional genomic approaches have been used to identified genes associated with L-asparaginase resistance/sensitivity in ALL patient samples or cell lines [66-70]. However, most of these genes have not been broadly studied on their cellular functions in drug responses.

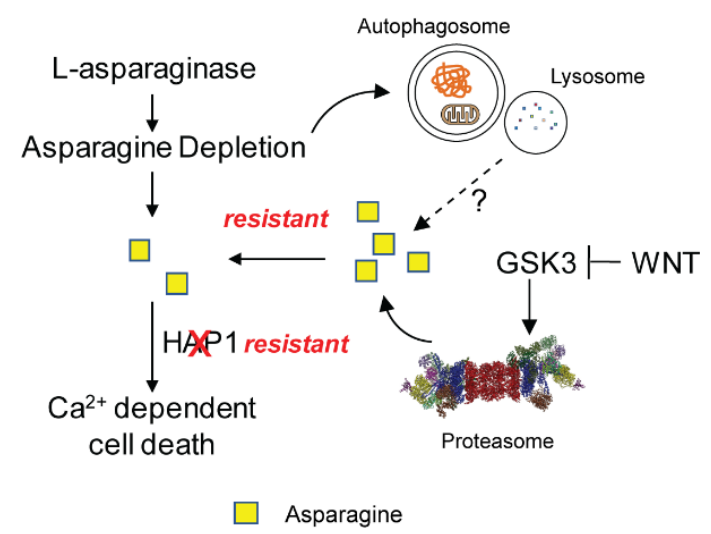

Figure 2. Mechanisms driving L-asparaginase resistance independently of ASNS. Potential contribution of proteolytic/autophagic scavenging of asparagine and $\mathrm{Ca}^{2+}$-dependent cell death inhibition to L-asparaginase resistance.

In summary, the expression of ASNS in ALL cells particularly following L-asparaginase treatment is a key factor to drive therapeutic resistance. Amino acid scavenging through proteolysis and autophagy or inhibition of downstream signaling cascade, such as calcium flux, can also contribute the process. However, whether ASNS expression is a clinical predictor for therapeutic response is context-dependent and warrants further investigation.

\section{The Role of Asparagine in Other Types of Cancer}

Even though clinical application of L-asparaginase is limited to ALL and some types of NK/T cell lymphoma, growing evidence suggests that asparagine bioavailability can play a critical role in the progression of other types of cancer. Along this line, various pre-clinical models have demonstrated the potential to combine L-asparaginase with other treatment or to restrict dietary asparagine as a means to treat cancer (Table 1). 


\subsection{Asparagine in Promoting Solid Tumor Progression}

The initial attention to asparagine in solid tumor progression was drawn by a seminal work showing that extracellular supplementation of asparagine can support tumor cell survival when exogenous glutamine is depleted [71]. Later on, similar phenomenon was observed in other types of proliferating mammalian cells [72,73], indicating a broader impact of the discovery. Since glutamine is often found to be limited in the tumor microenvironment [74], these studies provided the foundational basis in targeting asparagine bioavailability to prevent tumor cell adaptation to the lack of environmental glutamine. Mechanistically, asparagine prevents glutamine-depletion-induced ER stress in brain tumor cells [71]. Interestingly, a follow-up study from the same group found that asparagine can even support epithelial breast cancer cells to proliferate in the absence of exogenous glutamine [25]. In this context, asparagine supports de novo biosynthesis of glutamine through enhancing the expression of glutamine synthetase (GLUL) [25].

Table 1. Summary of the role of asparagine in solid tumor studies.

\begin{tabular}{|c|c|c|}
\hline References & Biological Processes & Functions \\
\hline Zhang J, [71] & Glutamine starvation & Suppresses ER stress and apoptosis \\
\hline Pavlova NN, [25] & Glutamine starvation & $\begin{array}{l}\text { Supports GLUL expression and } \\
\text { glutamine biosynthesis }\end{array}$ \\
\hline Gwinn DM, [75] & KRAS-driven lung cancer & $\begin{array}{l}\text { NRF2-dependent de novo biosynthesis to } \\
\text { support tumor cell growth }\end{array}$ \\
\hline LeBoeuf SE, [76] & KRAS-driven lung cancer & $\begin{array}{l}\text { Demand for uptake to mitigate } \\
\text { NRF2-dependent glutamate export }\end{array}$ \\
\hline Linares JF, [77] & Prostate cancer & $\begin{array}{l}\text { Secreted by CAFs to support tumor } \\
\text { cell growth }\end{array}$ \\
\hline Knott SRV, [78] & Breast cancer metastasis & $\begin{array}{l}\text { Supports lung metastasis via EMT } \\
\text { gene expression }\end{array}$ \\
\hline Halbrook CJ, [79] & Pancreatic cancer & Protect tumor cells from ETC inhibition \\
\hline Hinze L, [80] & Colorectal cancer & $\begin{array}{l}\text { GSK3-dependent proteolytic scavenging to } \\
\text { protect from L-asparaginase treatment }\end{array}$ \\
\hline
\end{tabular}

Recent work in a non-small-cell lung cancer (NSCLC) model shows that oncogenic KRAS signaling can hijack asparagine biosynthesis to support tumor growth [75]. Mechanistically, KRAS activates NRF2, a key transcription factor for anti-oxidant defense, through the downstream PI3K/AKT pathway. As a result, NRF2 induces the expression of ATF4 transcription factor to drive the transcription of ASNS gene. Of interest, the manuscript shows that AKT inhibitors can synergistically inhibit tumor growth in mice when combined with L-asparaginase [75]. In a separate study, KEAP1 mutant NSCLC cells were found to exhibit increased dependency on asparagine as well as several other nonessential amino acids (NEAAs) [76]. Since KEAP1 is a negative regulator of NRF2, the study demonstrated that enhanced NRF2 activity drives the import of cystine at the expense of intracellular glutamate, which is a key intermediate for the biosynthesis of NEAAs, including asparagine. As a result, L-asparaginase treatment or dietary restriction on asparagine can selectively inhibit the growth of KEAP1 mutant NSCLC cells in xenograft tumor models. However, further investigation is needed to reconcile whether NRF2 activation creates dependency on exogenous asparagine or dependency on its de novo biosynthesis.

Solid tumor cells can also acquire asparagine from their microenvironment via stroma cell release. In a prostate cancer model, cancer associated fibroblasts (CAFs) can enhance asparagine biosynthesis and release asparagine to support tumor cell growth [77]. In this model, autophagy adaptor protein p62 is a key regulator to repress the expression of ATF4 through ubiquitin-mediated degradation. As a result, loss of p62 in the CAFs supports prostate cancer growth in a mouse model through ATF4-ASNS axis, likely by facilitating tumor cell adaptation to glutamine-limiting environment. However, glutamine is an indispensable precursor for asparagine biosynthesis. Why CAFs, but not tumor 
cells themselves, can produce asparagine in a glutamine-limiting environment warrants further investigation.

Asparagine bioavailability can also affect tumor progression during specific stages. A recent work done in a metastatic breast cancer murine model shows that shRNA inhibition of ASNS expression selectively prevents lung metastasis while not perturbing tumor growth in the primary sites [78]. Mice treated with L-asparaginase or fed with asparagine-free diet had significantly reduced lung metastasis. This work provides evidence that environmental asparagine might be limiting in the lung or during the process of lung metastasis and thus render de novo biosynthesis to be essential. Mechanistically, asparagine restriction reduces the expression of genes involved in the epithelial-mesenchymal transition (EMT), a key step for metastasis to initiate [78]. Since EMT process happens at the primary sites, it still warrants further investigation on the relative amount of asparagine needed for primary tumor growth versus EMT process.

The ability of asparagine to modulate tumor progression can also be reflected at the stage when tumor cells respond to therapeutics. A recent study (in preprint) shows that clonal heterogeneity within a tumor tissue can contribute to therapeutic resistance through asparagine biosynthesis [79]. In a mouse pancreatic tumor model, the authors discovered metabolic heterogeneity within a tumor tissue, which leads to differential responses to electron transfer chain inhibitors (ETCi). Of interest, clones that were sensitive to ETCi become resistant when they are co-cultured with clones that are intrinsically resistant to ETCi. Through comprehensive metabolic analysis, the manuscript identified asparagine as a key metabolite secreted from the resistant clones, which can feed the sensitive clones to drive their resistance to ETCi. Since a major tumor suppressive effect of ETCi is via restricting aspartate production [81,82], the manuscript found that asparagine supplementation can preserve aspartate pool in sensitive clones likely by diverging aspartate from asparagine biosynthesis [79]. Furthermore, L-asparaginase treatment sensitizes tumor cells to phenformin, a complex I inhibitor, in an allograft mouse pancreatic tumor model in vivo.

Similar to findings in leukemic blasts, the synergy between L-asparaginase and WNT pathway activation can also be observed in solid tumors. Similar to ALL cells, the same group found that WNT activation by R-spondin fusion in colorectal cancers drives selective sensitivity to L-asparaginase treatment [80]. Of interest, APC mutations that activate betacatenin downstream of GSK3 shows little response to L-asparaginase treatment. Mechanistically, APC mutant colorectal cancer cells retain high GSK3 activities to drive proteolytic scavenging of asparagine; in contrast, R-spondin fusion suppresses GSK3 activation to de-repress beta-catenin activity, and thus is unable to activate GSK3-dependent proteolysis [80]. Similar to ALL cells, it is unclear whether this GSK3-dependent sensitivity to L-asparaginase involves the regulation of ASNS expression or not.

Taken together, these work shows that asparagine plays a critical role as a key metabolite for tumor cell growth or survival at various stages during tumor progression. When environmental glutamine levels decline, asparagine can protect tumor cells from apoptosis or even support de novo glutamine biosynthesis in a context-dependent manner. In addition, genetic lesions in tumor cells can alter their dependencies on de novo biosynthesis or extracellular acquisition of asparagine, which provides rationale for targeted therapeutics. Furthermore, asparagine bioavailability can affect tumor progression at specific stages, including lung metastasis or response to treatment through stage-specific mechanisms.

\subsection{Asparagine Regulates Cancer Cell Signaling}

In addition to its canonical role as an amino acid for protein synthesis, asparagine has been found to have non-metabolic roles in regulating tumor-associated signaling. These studies will provide not only a comprehensive picture into the molecular mechanisms by which asparagine facilitates tumor progression, but also insights into the potential reasons for therapeutic resistance following asparagine depletion.

The initial attention of asparagine in regulating cancer cell signaling was reported by a seminal work demonstrating that asparagine can activate mTORC1 to drive protein 
synthesis and nucleotide biosynthesis [83]. The ability of asparagine to activate mTORC1 relies at least partially on its ability to function as an antiporter exchange factor for the import other amino acids (Figure 3A). Recently, the same group found that the ability of asparagine to activate $\mathrm{mTORC} 1$ represents a key adaptive strategy for tumor cells to mitigate ETC inhibition-induced stress, which is coupled to ATF4 activation [84]. This work provides an alternative explanation for the synergy between ETC inhibition and asparagine restriction [79] (Figure 3A), and also brings up the question of whether asparagine or aspartate is the most limiting metabolite to drive ETC inhibition-associated phenomenon in tumor cells. Furthermore, in addition to functioning as an exchange factor for mTORC1 activation, asparagine can also activate mTORC1 directly through an ADP-ribosylation factor 1 (Arf1)-dependent but Rag GTPase-independent mechanism [85] (Figure 3A).

(A)

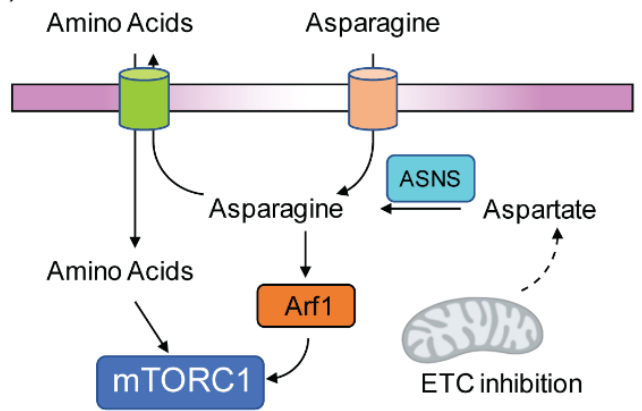

(C)

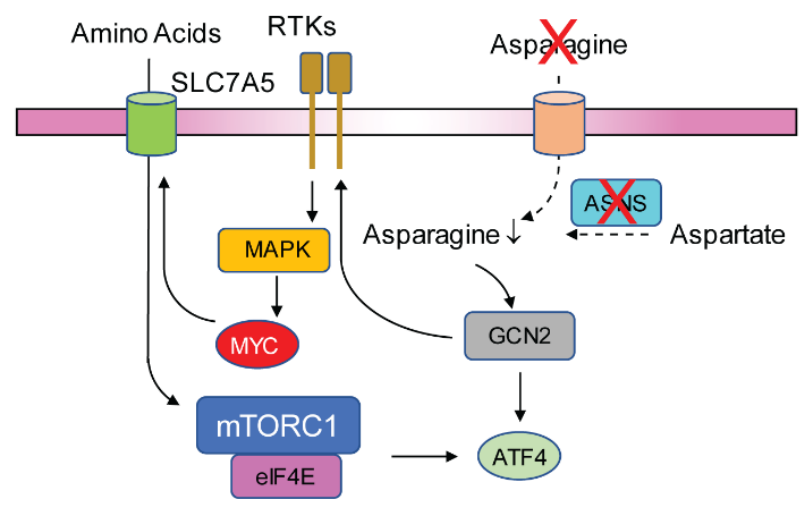

(B)

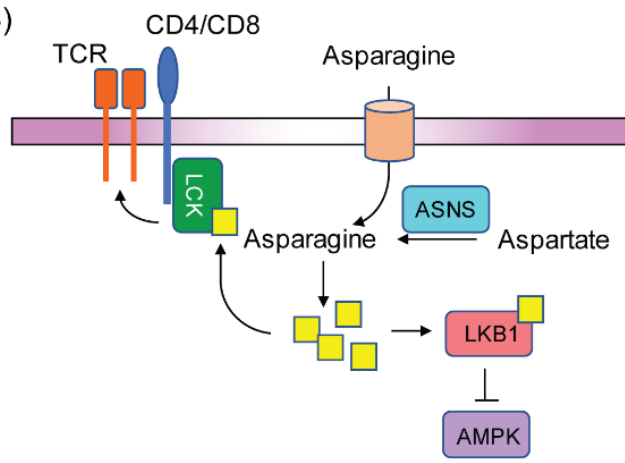

Figure 3. Signaling pathways regulated by asparagine or its depletion. (A) Asparagine activates mTORC1 through Arf1 or through importing other amino acids. Asparagine can also maintain mTORC1 activity during ETC inhibition. (B) Asparagine can directly bind to LCK or LKB1 to modulate their activities. As a result, asparagine is a positive regulator of TCR signaling and a negative regulator of AMPK pathway. (C) Asparagine depletion activates MAPK pathway through the induction of RTKs. MAPK activation leads to the engagement of MYC-SLC7A5 axis to support amino acid uptake, which subsequently activates mTORC1/eIF4e to support the translation of ATF4 protein.

Asparagine can also alter the activities of signaling molecules through direct binding. A recent work shows that asparagine can bind to LKB1, an upstream suppressor of the AMP-activated protein kinase (AMPK), to promote the inhibitory effect of LKB1 on AMPK [86] (Figure 3B). As a result, intracellular depletion of asparagine activates AMPK, which induces p53 phosphorylation to further suppress ASNS transcription through promoter recruitment. It remains to be determined why tumor cells use this feedforward loop to control the expression of ASNS when they suffer from asparagine limitation. In addition, it will be interesting to investigate whether p53 status can be used to predict sensitivity to asparagine depletion in a broader spectrum of tumors, considering its frequent loss 
of function in cancers. Of interest, the same group recently reported that asparagine can directly enhance the $\mathrm{T}$ cell receptor (TCR) signaling to promote CD8+ T cell activation and its anti-tumor responses [87]. Mechanistically, asparagine directly binds to lymphocytespecific protein tyrosine kinase (LCK) to induce its autophosphorylation on Tyr 394 and 505, which consequently leads to enhanced TCR signaling (Figure 3B). More importantly, immunocompetent mice pre-fed with asparagine-free diet shows decreased activities of $\mathrm{CD} 8+\mathrm{T}$ cells and compromised anti-tumor responses in a subcutaneous B16 melanoma model [87]. This study also highlights the potential challenge of using T cell-based therapy in cancer patients if they will be treated with L-asparaginase.

ALL cells adapt to asparagine depletion through engaging the GCN2/eIF2 $\alpha /$ ATF4 axis to turn on the expression of ASNS. However, the GCN2/eIF2 $\alpha$ feedback loop seems not to be sufficient to induce the ATF4 in melanoma cells to mediate adaptation. Indeed, melanoma cells rely on GCN2/eIF2 $\alpha$ axis to induce the expression of receptor tyrosine kinases (RTKs), which initiates a signaling cascade through MAPK/mTORC1/eIF4E axis to achieve maximal induction of ATF4 [88] (Figure 3C). This study demonstrates that MAPK inhibitors can synergize with L-asparaginase in a subcutaneous mouse melanoma model through preventing the ATF4 accumulation and ASNS induction. In addition, the same group reported recently that c-MYC is a key downstream component of the MAPK for mTORC1 activation [89]. This process is regulated through c-MYC-dependent transcription of amino acid transporters, such as SLC7A5. As a result, increased essential amino acid import triggers mTORC1 activation (Figure 3C).

Taken together, these studies shed light into the signaling regulatory role of asparagine. Although mTORC1 can either be activated by asparagine or can be feedback turned on through RTKs/MAPK during asparagine starvation, its sustained activation is critical to couple amino acid availability to protein synthesis and other anabolic reactions. Asparagine depletion can also activate AMPK, an energy sensor in cells. This suggests that the lack of intracellular asparagine may confer a non-anabolic status to preserve energy to mitigate the stress responses. Furthermore, the fact that asparagine can facilitate CD8+ T cell activation and their anti-tumor responses will bring up the challenge of using L-asparaginase or asparagine-restricted diet in cancer patients concurrent with immunotherapy.

\section{Conclusions}

In summary, asparagine is a key metabolite in supporting tumor progression. Elucidating the molecular mechanisms that drive resistance to L-asparaginase treatment in ALL will further advance our understanding of why other cancers do not respond to L-asparaginase treatment. As a result, combining L-asparaginase with novel targeted therapeutics overcoming resistance, will potentially broaden its application in other cancers, in the future. Further studies on immune-tumor interaction in specific tumor microenvironments are needed urgently to tailor potential therapeutic strategies to preserve anti-tumor immune responses while targeting resistant cancer.

Author Contributions: Conceptualization, S.B. and J.Z.; writing, J.J., S.B., and J.Z. All authors have read and agreed to the published version of the manuscript.

Funding: This research was funded by NIH/NCI CA244625, ASH Scholar Award and St. Baldrick's Foundation.

Conflicts of Interest: The authors declare no conflict of interest.

\section{References}

1. Palm, W.; Thompson, C.B. Nutrient acquisition strategies of mammalian cells. Nature 2017, 546, 234-242. [CrossRef]

2. Choi, B.H.; Coloff, J.L. The Diverse Functions of Non-Essential Amino Acids in Cancer. Cancers 2019, 11, 675. [CrossRef] [PubMed]

3. Avramis, V.I. Asparaginases: Biochemical pharmacology and modes of drug resistance. Anticancer Res. 2012, 32, $2423-2437$. [PubMed] 
4. Kidd, J.G. Regression of transplanted lymphomas induced in vivo by means of normal guinea pig serum. I. Course of transplanted cancers of various kinds in mice and rats given guinea pig serum, horse serum, or rabbit serum. J. Exp. Med. 1953, 98, 565-582. [CrossRef]

5. Kidd, J.G. Regression of transplanted lymphomas induced in vivo by means of normal guinea pig serum. II. Studies on the nature of the active serum constituent: Histological mechanism of the regression: Tests for effects of guinea pig serum on lymphoma cells in vitro: Discussion. J. Exp. Med. 1953, 98, 583-606. [PubMed]

6. Broome, J.D. Evidence that the L-asparaginase activity of guinea pig serum is responsible for its antilymphoma effects. Nature 1961, 191, 2. [CrossRef]

7. Broome, J.D. Evidence that the L-asparaginase of guinea pig serum is responsible for its antilymphoma effects. II. Lymphoma 6C3HED cells cultured in a medium devoid of L-asparagine lose their susceptibility to the effects of guinea pig serum in vivo. J. Exp. Med. 1963, 118, 121-148. [CrossRef]

8. Broome, J.D. Evidence that the L-asparaginase of guinea pig serum is responsible for its antilymphoma effects. I. Properties of the L-asparaginase of guinea pig serum in relation to those of the antilymphoma substance. J. Exp. Med. 1963, 118, 99-120. [CrossRef]

9. Yellin, T.O.; Wriston, J.C., Jr. Purification and properties of guinea pig serum asparaginase. Biochemistry 1966, 5, 1605-1612. [CrossRef] [PubMed]

10. Clarkson, B.; Krakoff, I.; Burchenal, J.; Karnofsky, D.; Golbey, R.; Dowling, M.; Oettgen, H.; Lipton, A. Clinical results of treatment with E. coli L-asparaginase in adults with leukemia, lymphoma, and solid tumors. Cancer 1970, 25, 279-305. [CrossRef]

11. Capizzi, R.L.; Bertino, J.R.; Skeel, R.T.; Creasey, W.A.; Zanes, R.; Olayon, C.; Peterson, R.G.; Handschumacher, R.E. L-asparaginase: Clinical, biochemical, pharmacological, and immunological studies. Ann. Intern. Med. 1971, 74, 893-901. [CrossRef]

12. Abuchowski, A.; Kazo, G.M.; Verhoest, C.R., Jr.; Van Es, T.; Kefkewitz, D.; Nucci, M.L.; Viau, A.T.; Davis, F.F. Cancer therapy with chemically modified enzymes. I. Antitumor properties of polyethylene glycoL-asparaginase conjugates. Cancer Biochem. Biophys. 1984, 7, 175-186.

13. Koerholz, D.; Brueck, M.; Nuenberger, W.; Juergens, H.; Goebel, U.; Wahn, V. Chemical and immunological characteristics of four different L-asparaginase preparations. Eur. J. Haematol. 1989, 42, 417-424. [CrossRef]

14. Asselin, B.L.; Whitin, J.C.; Coppola, D.J.; Rupp, I.P.; Sallan, S.E.; Cohen, H.J. Comparative pharmacokinetic studies of three asparaginase preparations. J. Clin. Oncol. 1993, 11, 1780-1786. [CrossRef] [PubMed]

15. Ahlke, E.; Nowak-Gottl, U.; Schulze-Westhoff, P.; Werber, G.; Borste, H.; Wurthwein, G.; Jurgens, H.; Boos, J. Dose reduction of asparaginase under pharmacokinetic and pharmacodynamic control during induction therapy in children with acute lymphoblastic leukaemia. Br. J. Haematol. 1997, 96, 675-681. [CrossRef] [PubMed]

16. Vieira Pinheiro, J.P.; Ahlke, E.; Nowak-Gottl, U.; Hempel, G.; Muller, H.J.; Lumkemann, K.; Schrappe, M.; Rath, B.; Fleischhack, G.; Mann, G.; et al. Pharmacokinetic dose adjustment of Erwinia asparaginase in protocol II of the paediatric ALL/NHL-BFM treatment protocols. Br. J. Haematol. 1999, 104, 313-320. [CrossRef] [PubMed]

17. Duval, M.; Suciu, S.; Ferster, A.; Rialland, X.; Nelken, B.; Lutz, P.; Benoit, Y.; Robert, A.; Mane, A.-M.; Vilmer, E.; et al. Comparison of Escherichia coli-asparaginase with Erwinia-asparaginase in the treatment of childhood lymphoid malignancies: Results of a randomized European Organisation for Research and Treatment of Cancer-Children's Leukemia Group phase 3 trial. Blood 2002, 99, 2734-2739. [CrossRef]

18. Klug Albertsen, B.; Schmiegelow, K.; Schrøder, H.; Carlsen, N.T.; Rosthøj, S.; Avramis, V.I.; Jakobsen, P. Anti-Erwinia asparaginase antibodies during treatment of childhood acute lymphoblastic leukemia and their relationship to outcome: A case-control study. Cancer Chemother. Pharm. 2002, 50, 117-120. [CrossRef]

19. Boos, J.; Werber, G.; Ahlke, E.; Schultze-Westhoff, P.; Nowak-Gottl, U.; Würthwein, G.; Verspohl, E.J.; Ritter, J.; Jürgens, H. Monitoring of asparaginase activity and asparagine levels in children on different asparaginase preparations. Eur. J. Cancer 1996, 32, 1544-1550. [CrossRef]

20. Angiolillo, A.L.; Schore, R.J.; Meenakshi, D.; Borowitz, M.J.; Carroll, A.J.; Gastier-Foster, J.M.; Heerema, N.A.; Keilani, T.; Lane, A.R.; Loh, M.L.; et al. Pharmacokinetic and pharmacodynamic properties of calaspargase pegol Escherichia coli L-asparaginase in the treatment of patients with acute lymphoblastic leukemia: Results from Children's Oncology Group Study AALL07P4. J. Clin. Oncol. 2014, 32, 3874-3882. [CrossRef]

21. Tallal, L.; Tan, C.; Oettgen, H.; Wollner, N.; McCarthy, M.; Helson, L.; Burchenal, J.; Karnofsky, D.; Murpjy, M.L. E. coli L-asparaginase in the treatment of leukemia and solid tumors in 131 children. Cancer 1970, 25, 306-320. [CrossRef]

22. Worton, K.S.; Kerbel, R.S.; Andrulis, I.L. Hypomethylation and reactivation of the asparagine synthetase gene induced by L-asparaginase and ethyl methanesulfonate. Cancer Res. 1991, 51, 985-989.

23. Ren, Y.; Soy, S.; Ding, Y.; Iqbal, J.; Broome, J.D. Methylation of the asparagine synthetase promoter in human leukemic cell lines is associated with a specific methyl binding protein. Oncogene 2004, 23, 3953-3961. [CrossRef] [PubMed]

24. Rigouin, C.; Nguyen, H.A.; Schalk, A.M.; Lavie, A. Discovery of human-like L-asparaginases with potential clinical use by directed evolution. Sci. Rep. 2017, 7, 10224. [CrossRef] [PubMed]

25. Pavlova, N.N.; Hui, S.; Ghergurovich, J.M.; Fan, J.; Intlekofer, A.M.; White, R.M.; Rabinowitz, J.D.; Thompson, C.B.; Zhang, J. As Extracellular Glutamine Levels Decline, Asparagine Becomes an Essential Amino Acid. Cell Metab. 2018, 27, 428-438. [CrossRef] [PubMed]

26. Avramis, V.I.; Sencer, S.; Periclou, A.P.; Sather, H.; Bostrom, B.C.; Cohen, L.J.; Ettinger, A.G.; Ettinger, L.J.; Franklin, J.; Gaynon, P.S.; et al. A randomized comparison of native Escherichia coli asparaginase and polyethylene glycol conjugated asparaginase 
for treatment of children with newly diagnosed standard-risk acute lymphoblastic leukemia: A Children's Cancer Group study. Blood 2002, 99, 1986-1994. [CrossRef]

27. Jarrar, M.; Sencer, S.; Periclou, A.P.; Sather, H.; Bostrom, B.C.; Cohen, L.J.; Ettinger, A.G.; Ettinger, L.J.; Franklin, J.; Gaynon, P.S.; et al. Asparagine depletion after pegylated E. coli asparaginase treatment and induction outcome in children with acute lymphoblastic leukemia in first bone marrow relapse: A Children's Oncology Group study (CCG-1941). Pediatr. Blood Cancer 2006, 47, 141-146. [CrossRef]

28. Silverman, L.B.; Supko, J.G.; Stevenson, K.; Woodward, C.; Vrooman, V.M.; Neuberg, D.S.; Asselin, B.L.; Athale, U.H.; Clavell, L.; Cole, P.D.; et al. Intravenous PEG-asparaginase during remission induction in children and adolescents with newly diagnosed acute lymphoblastic leukemia. Blood 2010, 115, 1351-1353. [CrossRef]

29. Douer, D.; Yampolsky, H.; Cohen, L.J.; Watkins, K.; Levine, A.M.; Periclou, A.P.; Avramis, V.I. Pharmacodynamics and safety of intravenous pegaspargase during remission induction in adults aged 55 years or younger with newly diagnosed acute lymphoblastic leukemia. Blood 2007, 109, 2744-2750. [CrossRef]

30. Holcenberg, J.S.; Teller, D.C. Physical properties of antitumor glutaminase-asparaginase from Pseudomonas 7A. J. Biol. Chem. 1976, 251, 5375-5380. [CrossRef]

31. Panosyan, E.H.; Grigoryan, R.S.; Avramis, I.A.; Seibel, N.L.; Gaynon, P.S.; Siegel, S.E.; Fingert, H.J.; Avramis, V.I. Deamination of glutamine is a prerequisite for optimal asparagine deamination by asparaginases in vivo (CCG-1961). Anticancer Res. 2004, 24, 1121-1125.

32. Nguyen, H.A.; Su, Y.; Zhang, J.Y.; Antanasijevic, A.; Caffrey, M.; Schalk, A.M.; Liu, L.; Rondelli, R.; Oh, A.; Mahmud, D.L.; et al. A Novel L-Asparaginase with low L-Glutaminase Coactivity Is Highly Efficacious against Both T- and B-cell Acute Lymphoblastic Leukemias In vivo. Cancer Res. 2018, 78, 1549-1560. [CrossRef]

33. Chan, W.K.; Horvath, T.D.; Tan, L.; Link, T.; Harutyunyan, K.G.; Pontikos, M.A.; Anishkin, A.; Du, D.; Martin, L.A.; Yin, E.; et al. Glutaminase Activity of L-Asparaginase Contributes to Durable Preclinical Activity against Acute Lymphoblastic Leukemia. Mol. Cancer Ther. 2019, 18, 1587-1592. [CrossRef] [PubMed]

34. Chan, W.K.; Lorenzi, P.L.; Anishkin, A.; Purwaha, P.; Rogers, D.M.; Sukharev, S.; Rempe, S.B.; Weinstein, J.N. The glutaminase activity of L-asparaginase is not required for anticancer activity against ASNS-negative cells. Blood 2014, 123, 3596-3606. [CrossRef]

35. Silverman, L.B.; Declerck, L.; Gelber, R.D.; Kimball, D.; Asselin, B.L.; Barr, R.D.; Clavell, L.A.; Huwitz, C.A.; Moghrabi, A.; Samson, Y.; et al. Results of Dana-Farber Cancer Institute Consortium protocols for children with newly diagnosed acute lymphoblastic leukemia (1981-1995). Leukemia 2000, 14, 2247-2256. [CrossRef] [PubMed]

36. Abshire, T.C.; Pollock, B.H.; Billett, A.L.; Bradley, P.; Buchanan, G.R. Weekly polyethylene glycol conjugated L-asparaginase compared with biweekly dosing produces superior induction remission rates in childhood relapsed acute lymphoblastic leukemia: A Pediatric Oncology Group Study. Blood 2000, 96, 1709-1715. [CrossRef]

37. Hawkins, D.S.; Pollock, B.H.; Billett, A.L.; Bradley, P.; Buchanan, G.R. Asparaginase pharmacokinetics after intensive polyethylene glycoL-conjugated L-asparaginase therapy for children with relapsed acute lymphoblastic leukemia. Clin. Cancer Res. 2004, 96, 5335-5341. [CrossRef] [PubMed]

38. Winter, S.S.; Holdsworth, M.T.; Devidas, M.; Reisch, D.W.; Chauvenet, A.; Ravindranath, A.; Ducore, J.M.; Amyhlon, M.D. Antimetabolite-based therapy in childhood T-cell acute lymphoblastic leukemia: A report of POG study 9296. Pediatr. Blood Cancer 2006, 46, 179-186. [CrossRef]

39. Yang, L.; Panetta, J.C.; Cai, X.; Yang, W.; Pei, D.; Cheng, C.; Konegay, N.; Pui, C.-H.; Relling, M.V. Asparaginase may influence dexamethasone pharmacokinetics in acute lymphoblastic leukemia. J. Clin. Oncol. 2008, 26, 1932-1939. [CrossRef]

40. Schrappe, M.; Reiter, A.; Ludwig, W.D.; Harbott, J.; Zimmermann, M.; Hiddemann, W.; Niemeyer, C.; Henze, G.; Feldges, A.; Zintl, F.; et al. Improved outcome in childhood acute lymphoblastic leukemia despite reduced use of anthracyclines and cranial radiotherapy: Results of trial ALL-BFM 90. German-Austrian-Swiss ALL-BFM Study Group. Blood 2000, 95, 3310-3322.

41. Amylon, M.D.; Shuster, J.; Pullen, J.; Berard, C.; Link, M.P.; Wharam, M.; Katz, J.; Yu, A.; Laver, J.; Ravindranath, Y.; et al. Intensive high-dose asparaginase consolidation improves survival for pediatric patients with $\mathrm{T}$ cell acute lymphoblastic leukemia and advanced stage lymphoblastic lymphoma: A Pediatric Oncology Group study. Leukemia 1999, 13, 335-342. [CrossRef] [PubMed]

42. Salzer, W.L.; Devidas, M.; Carroll, W.L.; Winick, N.; Pullen, J.; Hunger, S.P.; Camitta, B.A. Long-term results of the pediatric oncology group studies for childhood acute lymphoblastic leukemia 1984-2001: A report from the children's oncology group. Leukemia 2010, 24, 355-370. [CrossRef] [PubMed]

43. Evans, W.E.; Tsiatis, A.; Rivera, G.; Murphy, S.B.; Dahl, G.V.; Denison, M.; Crom, V.R.; Barker, L.F.; Mauer, A.M. Anaphylactoid reactions to Escherichia coli and Erwinia asparaginase in children with leukemia and lymphoma. Cancer 1982, 49, 1378-1383. [CrossRef]

44. Cheung, N.K.; Chau, I.Y.; Coccia, P.F. Antibody response to Escherichia coli L-asparaginase. Prognostic significance and clinical utility of antibody measurement. Am. J. Pediatr. Hematol. Oncol. 1986, 8, 99-104.

45. Panosyan, E.H.; Seibel, N.L.; Martin-Aragon, S.; Gaynon, P.S.; Avramis, I.A.; Sather, H.; Franklin, J.; Nachman, J.; Ettinger, L.; Mei, L.A.; et al. Asparaginase antibody and asparaginase activity in children with higher-risk acute lymphoblastic leukemia: Children's Cancer Group Study CCG-1961. J. Pediatr. Hematol. Oncol. 2004, 26, 217-226. [CrossRef] 
46. van der Meer, L.T.; Terry, S.Y.; van Ingen Schenau, D.S.; Andree, K.C.; Franssen, G.M.; Roeleveld, D.M.; Metselaar, J.M.; Reinheckel, T.; Hoogerbrugge, P.M.; Boerman, O.C.; et al. In vivo Imaging of Antileukemic Drug Asparaginase Reveals a Rapid Macrophage-Mediated Clearance from the Bone Marrow. J. Nucl. Med. 2017, 58, 214-220. [CrossRef]

47. Balasubramanian, M.N.; Butterworth, E.A.; Kilberg, M.S. Asparagine synthetase: Regulation by cell stress and involvement in tumor biology. Am. J. Physiol. Endocrinol. Metab. 2013, 304, E789-E799. [CrossRef]

48. Aslanian, A.M.; Fletcher, B.S.; Kilberg, M.S. Asparagine synthetase expression alone is sufficient to induce L-asparaginase resistance in MOLT-4 human leukaemia cells. Biochem. J. 2001, 357, 321-328. [CrossRef]

49. Ding, Y.; Li, Z.; Broome, J.D. Epigenetic changes in the repression and induction of asparagine synthetase in human leukemic cell lines. Leukemia 2005, 19, 420-426. [CrossRef]

50. Nakamura, A.; Nambu, T.; Ebara, S.; Hasegawa, Y.; Toyoshima, K.; Tsuchiya, Y.; Tomita, D.; Fujimoto, J.; Kurasawa, O.; Takahara, C.; et al. Inhibition of GCN2 sensitizes ASNS-low cancer cells to asparaginase by disrupting the amino acid response. Proc. Natl. Acad. Sci. USA 2018, 115, E7776-E7785. [CrossRef]

51. Jiang, J.; Srivastava, S.; Seim, G.; Pavlova, N.N.; King, B.; Zou, L.; Zhang, C.; Zhong, M.; Feng, H.; Kapur, R.; et al. Promoter demethylation of the asparagine synthetase gene is required for ATF4-dependent adaptation to asparagine depletion. J. Biol. Chem. 2019, 294, 18674-18684. [CrossRef]

52. Chen, H.; Pan, Y.X.; Dudenhausen, E.E.; Kilberg, M.S. Amino acid deprivation induces the transcription rate of the human asparagine synthetase gene through a timed program of expression and promoter binding of nutrient-responsive basic region/leucine zipper transcription factors as well as localized histone acetylation. J. Biol. Chem. 2004, 279, 50829-50839.

53. Williams, R.T.; Guarecuco, R.; Gates, L.A.; Barrows, D.; Passarelli, M.C.; Carey, B.; Baudrier, L.; Jeewajee, S.; La, K.; Prozer, B.; et al. ZBTB1 Regulates Asparagine Synthesis and Leukemia Cell Response to L-Asparaginase. Cell Metab. 2020, 31, 852-861. [CrossRef] [PubMed]

54. Aslanian, A.M.; Kilberg, M.S. Multiple adaptive mechanisms affect asparagine synthetase substrate availability in asparaginaseresistant MOLT-4 human leukaemia cells. Biochem. J. 2001, 358, 59-67. [CrossRef] [PubMed]

55. Sun, J.; Nagel, R.; Zaal, E.A.; Ugalde, A.P.; Han, R.; Proost, N.; Song, J.-Y.; Pataskar, A.; Burylo, A.; Fu, H.; et al. SLC1A3 contributes to L-asparaginase resistance in solid tumors. EMBO J. 2019, 38, e102147. [CrossRef]

56. Jiang, J.; Srivastava, S.; Zhang, J. Starve Cancer Cells of Glutamine: Break the Spell or Make a Hungry Monster? Cancers 2019, 11, 804. [CrossRef] [PubMed]

57. Stams, W.A.; den Boer, M.L.; Beverloo, H.B.; Meijerink, J.P.; Stigter, R.L.; van Wering, E.R.; Janka-Schaub, G.E.; Slater, R.; Pieters, $R$. Sensitivity to L-asparaginase is not associated with expression levels of asparagine synthetase in $t(12 ; 21)+$ pediatric ALL. Blood 2003, 101, 2743-2747. [CrossRef] [PubMed]

58. Su, N.; Pan, Y.X.; Zhou, M.; Harvey, R.C.; Hunger, S.P.; Kilberg, M.S. Correlation between asparaginase sensitivity and asparagine synthetase protein content, but not mRNA, in acute lymphoblastic leukemia cell lines. Pediatr. Blood Cancer 2008, 50, $274-279$. [CrossRef]

59. Touzart, A.; Lengliné, E.; Latiri, M.; Belhocine, M.; Smith, C.; Thomas, X.; Spicuglia, S.; Puthier, D.; Pflumio, F.; Leguay, T.; et al. Epigenetic silencing affects L-asparaginase sensitivity and predicts outcome in T-ALL. Clin. Cancer Res. 2019, 25, $2483-2493$. [CrossRef]

60. Iwamoto, S.; Mihara, K.; Downing, J.R.; Pui, C.H.; Campana, D. Mesenchymal cells regulate the response of acute lymphoblastic leukemia cells to asparaginase. J. Clin. Investig. 2007, 117, 1049-1057. [CrossRef]

61. Ehsanipour, E.A.; Sheng, X.; Behan, J.W.; Wang, X.; Butturini, A.; Avramis, V.I.; Mittelman, S.D. Adipocytes cause leukemia cell resistance to L-asparaginase via release of glutamine. Cancer Res. 2013, 73, 2998-3006. [CrossRef] [PubMed]

62. Hinze, L.; Pfirrmann, M.; Karim, S.; Degar, J.; McGuckin, C.; Vinjamur, D.; Sacher, J.; Stevenson, K.E.; Neuberg, D.S.; Orellana, E.; et al. Synthetic Lethality of Wnt Pathway Activation and Asparaginase in Drug-Resistant Acute Leukemias. Cancer Cell 2019, 35, 664-676. [CrossRef] [PubMed]

63. Guo, J.Y.; Teng, X.; Laddha, S.V.; Ma, S.; Van Nostrand, S.C.; Yang, Y.; Khor, S.; Chan, C.S.; Rabinowitz, J.D.; White, E. Autophagy provides metabolic substrates to maintain energy charge and nucleotide pools in Ras-driven lung cancer cells. Genes. Dev. 2016, 30, 1704-1717. [CrossRef]

64. Takahashi, H.; Inoue, J.; Sakakguchi, K.; Takagi, M.; Mizutani, S.; Inazawa, J. Autophagy is required for cell survival under L-asparaginase-induced metabolic stress in acute lymphoblastic leukemia cells. Oncogene 2017, 36, 4267-4276. [CrossRef] [PubMed]

65. Lee, J.K.; Kang, S.; Wang, X.; Rosales, J.L.; Gao, X.; Byun, H.G.; Jin, Y.; Fu, S.; Wang, J.; Lee, K.-Y. HAP1 loss confers L-asparaginase resistance in ALL by downregulating the calpain-1-Bid-caspase-3/12 pathway. Blood 2019, 133, 2222-2232. [CrossRef] [PubMed]

66. Holleman, A.; Cheok, M.H.; den Boer, M.L.; Yang, W.; Veerman, A.J.; Kazemier, K.M.; Pei, D.; Cheng, C.; Pui, C.-H.; Relling, M.V.; et al. Gene-expression patterns in drug-resistant acute lymphoblastic leukemia cells and response to treatment. N. Engl. J. Med. 2004, 351, 533-542. [CrossRef]

67. Holleman, A.; den Boer, M.L.; de Menezes, R.X.; Cheok, M.H.; Cheng, C.; Kazemier, K.M.; Janka-Schaub, G.E.; Gobel, U.; Graubner, U.B.; Evans, V.E.; et al. The expression of 70 apoptosis genes in relation to lineage, genetic subtype, cellular drug resistance, and outcome in childhood acute lymphoblastic leukemia. Blood 2006, 107, 769-776. [CrossRef] 
68. Holleman, A.; Boer, M.L.D.; Kazemier, K.M.; Beverloo, H.B.; von Bergh, A.R.; Janka-Schaub, G.E.; Pieters, R. Decreased PARP and procaspase-2 protein levels are associated with cellular drug resistance in childhood acute lymphoblastic leukemia. Blood 2005, 106, 1817-1823. [CrossRef]

69. Rousseau, J.; Gagné, V.; Labuda, M.; Beaubois, C.; Sinnett, D.; Laverdière, C.; Moghrabi, A.; Sallan, S.E.; Silverman, L.B.; Neuberg, D.; et al. ATF5 polymorphisms influence ATF function and response to treatment in children with childhood acute lymphoblastic leukemia. Blood 2011, 118, 5883-5890. [CrossRef]

70. Kang, S.M.; Rosales, J.L.; Meier-Stephenson, V.; Kim, S.; Lee, K.Y.; Narendran, A. Genome-wide loss-of-function genetic screening identifies opioid receptor mu1 as a key regulator of L-asparaginase resistance in pediatric acute lymphoblastic leukemia. Oncogene 2017, 36, 5910-5913. [CrossRef]

71. Zhang, J.; Fan, J.; Venneti, S.; Cross, J.R.; Takagi, T.; Bhinder, B.; Djaballah, H.; Kanai, M.; Cheng, E.H.; Judkins, A.R.; et al. Asparagine plays a critical role in regulating cellular adaptation to glutamine depletion. Mol. Cell 2014, 56, 205-218. [CrossRef] [PubMed]

72. Huang, H.; Vandekeere, S.; Kalucka, J.; Bierhansl, L.; Zecchin, A.; Brüning, U.; Visnagri, A.; Yuldasheva, N.; Goveia, J.; Cruys, B.; et al. Role of glutamine and interlinked asparagine metabolism in vessel formation. EMBO J. 2017, 36, 2334-2352. [CrossRef] [PubMed]

73. Zhu, Y.; Li, T.; Ramos da Silva, S.; Lee, J.J.; Lu, C.; Eoh, H.; Jung, J.U.; Gao, S.-J. A Critical Role of Glutamine and Asparagine gamma-Nitrogen in Nucleotide Biosynthesis in Cancer Cells Hijacked by an Oncogenic Virus. MBio 2017, 8, e01179-e01217. [CrossRef] [PubMed]

74. Zhang, J.; Pavlova, N.N.; Thompson, C.B. Cancer cell metabolism: The essential role of the nonessential amino acid, glutamine. EMBO J. 2017, 36, 1302-1315. [CrossRef]

75. Gwinn, D.M.; Lee, A.G.; Briones-Martin-del-Campo, M.; Conn, C.S.; Simpson, D.R.; Scott, A.I.; Le, A.; Cowan, T.M.; Ruggero, D.; Sweet-Cordero, E.A. Oncogenic KRAS Regulates Amino Acid Homeostasis and Asparagine Biosynthesis via ATF4 and Alters Sensitivity to L-Asparaginase. Cancer Cell 2018, 33, 91-107. [CrossRef]

76. LeBoeuf, S.E.; Wu, W.L.; Karakousi, T.R.; Karadal, B.; Jackson, S.R.; Davidson, S.M.; Wong, K.-K.; Koralov, S.B.; Sayin, V.I.; Papagiannakopoulos, T. Activation of Oxidative Stress Response in Cancer Generates a Druggable Dependency on Exogenous Non-essential Amino Acids. Cell Metab. 2020, 31, 339-350. [CrossRef]

77. Linares, J.F.; Cordes, T.; Duran, A.; Reina-Campos, M.; Valencia, T.; Ahn, C.S.; Castilla, E.A.; Moscat, J.; Metallo, C.M.; Diaz-Meco, M.T. ATF4-Induced Metabolic Reprograming Is a Synthetic Vulnerability of the p62-Deficient Tumor Stroma. Cell Metab. 2017, 26, 817-829. [CrossRef]

78. Knott, S.R.V.; Wagenblast, E.; Khan, S.; Kim, S.Y.; Soto, M.; Wagner, M.; Turgeon, M.-O.; Fish, L.; Erard, N.; Gable, A.L.; et al. Asparagine bioavailability governs metastasis in a model of breast cancer. Nature 2018, 554, 378-381. [CrossRef]

79. Halbrook, C.J.T.G.; McCarthy, A.; Nelson, B.S.; Sajjakulnukit, P.; Krall, A.S.; Mullen, P.J.; Zhang, L.; Batra, S.; Viale, A.; Stanger, B.Z.; et al. Clonal Heterogeneity Supports Mitochondrial Metabolism in Pancreatic Cancer. bioRxiv 2020. [CrossRef]

80. Hinze, L.; Labrosse, R.; Degar, J.; Han, T.; Schatoff, E.M.; Schreek, S.; Karim, S.; McGuckin, C.; Sacher, J.R.; Wagner, F.; et al. Exploiting the Therapeutic Interaction of WNT Pathway Activation and Asparaginase for Colorectal Cancer Therapy. Cancer Discov. 2020, 10, 1690-1705. [CrossRef]

81. Birsoy, K.; Wang, T.; Chen, W.W.; Freinkman, E.; Abu-Remaileh, M.; Sabatini, D.M. An Essential Role of the Mitochondrial Electron Transport Chain in Cell Proliferation Is to Enable Aspartate Synthesis. Cell 2015, 162, 540-551. [CrossRef] [PubMed]

82. Sullivan, L.B.; Gui, D.Y.; Hosios, A.M.; Bush, L.N.; Freinkman, E.; Vander Heiden, M.G. Supporting Aspartate Biosynthesis Is an Essential Function of Respiration in Proliferating Cells. Cell 2015, 162, 552-563. [CrossRef] [PubMed]

83. Krall, A.S.; Xu, S.; Graeber, T.G.; Braas, D.; Christofk, H.R. Asparagine promotes cancer cell proliferation through use as an amino acid exchange factor. Nat. Commun. 2016, 7, 11457. [CrossRef] [PubMed]

84. Krall, A.S.; Mullen, P.J.; Surjono, F.; Momcilovic, M.; Schmid, E.W.; Halbrook, C.J.; Thambundit, A.; Mittelman, S.D.; Lyssiotis, C.A.; Shackelford, D.B.; et al. Asparagine couples mitochondrial respiration to ATF4 activity and tumor growth. Cell Metab. 2021, 33, 1013-1026. [CrossRef] [PubMed]

85. Meng, D.; Yang, Q.; Wang, H.; Melick, C.H.; Navlani, R.; Frank, A.R.; Jewell, J.L. Glutamine and asparagine activate mTORC1 independently of Rag GTPases. J. Biol. Chem. 2020, 295, 2890-2899. [CrossRef] [PubMed]

86. Deng, L.; Yao, P.; Li, L.; Ji, F.; Zhao, S.; Xu, C.; Lan, X.; Jiang, P. p53-mediated control of aspartate-asparagine homeostasis dictates LKB1 activity and modulates cell survival. Nat. Commun. 2020, 11, 1755. [CrossRef] [PubMed]

87. Wu, J.; Li, G.; Li, L.; Li, D.; Dong, Z.; Jiang, P. Asparagine enhances LCK signalling to potentiate CD8(+) T-cell activation and anti-tumour responses. Nat. Cell Biol. 2021, 23, 75-86. [CrossRef]

88. Pathria, G.; Lee, J.S.; Hasnis, E.; Tandoc, K.; Scott, D.A.; Verma, S.; Feng, Y.; Larue, L.; Sahu, A.D.; Topisirovic, I. Translational reprogramming marks adaptation to asparagine restriction in cancer. Nat. Cell Biol. 2019, 21, 1590-1603. [CrossRef]

89. Pathria, G.; Verma, S.; Yin, J.; Scott, D.A.; Ronai, Z.E.A. MAPK signaling regulates c-MYC for melanoma cell adaptation to asparagine restriction. EMBO Rep. 2021, 22, e51436. [CrossRef] 